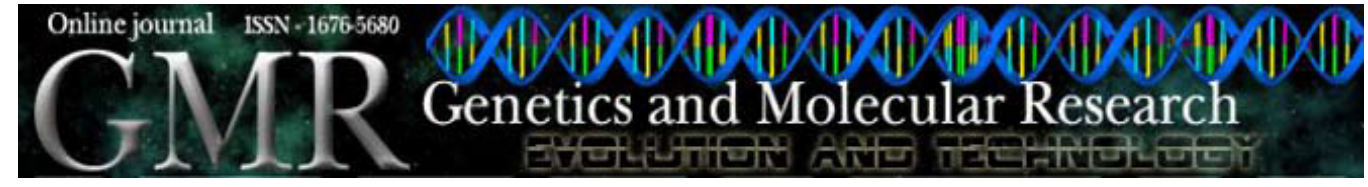

\title{
First morphogenetic identification of the fungal pathogen Colletotrichum musae (Phyllachoraceae) from imported bananas in Saudi Arabia
}

\author{
K.A. Abd-Elsalam ${ }^{1,2,3}$, S. Roshdy ${ }^{1}$, O.E. Amin ${ }^{1}$ and M. Rabani ${ }^{1}$ \\ ${ }^{1}$ Botany and Microbiology Department, King Saud University, \\ College of Science, Riyadh, Kingdom of Saudi Arabia \\ ${ }^{2}$ King Saud University, College of Science, \\ Abdul Rahman Al-Jeraisy DNA Research Chair, Riyadh, Saudi Arabia \\ ${ }^{3}$ Plant Pathology Research Institute, Agricultural Research Center, \\ Giza, Egypt \\ Corresponding author: K.A. Abd-Elsalam \\ E-mail: kamel200@ksu.edu.sa
}

Genet. Mol. Res. 9 (4): 2335-2342 (2010)

Received August 8, 2010

Accepted September 12, 2010

Published November 30, 2010

DOI 10.4238/vol9-4gmr972

\begin{abstract}
Colletotrichum musae is the causal agent of anthracnose in banana fruits; infection by this fungal pathogen results in severe post-harvest losses. Eleven C. musae isolates were obtained from infected imported banana fruit samples with anthracnose lesions collected from different markets in Riyadh, Saudi Arabia. The pathogenic, morphological, cultural, and molecular characteristics of these C. musae isolates were evaluated. The cultures had characteristic fast-growing sparse aerial mycelia that were white, with copious cinnamon conidial masses, conidia usually elliptical, and setae absent. An inoculation test was used to determine whether isolates could cause anthracnose symptoms on banana fruits. Necrotic lesions developed and orange-colored spore structures were later observed on these lesions. Microsatellite-primed PCR (MPPCR) was used to identify genetic variation among the C. musae
\end{abstract}


isolates. The dendrogram obtained from cluster analysis of the MPPCR fingerprints revealed a great deal of homogeneity among the isolates, shown by the formation of two clusters. Intraspecific similarity among the C. musae isolates ranged from 83 to $100 \%$. This is the first report demonstrating morphological and genetic variation within a population of C. musae in Saudi Arabia.

Key words: Colletotrichum musae; Morphogenetic identification; MP-PCR marker; Banana

\section{INTRODUCTION}

Bananas (Musa spp), which are entirely imported into Saudi Arabia from tropical countries, are considered to be one of the most popular fruits. For trading, banana fruits are generally harvested before ripening and stored at relatively low temperatures during transportation and market processing. Long transportation and storage period at markets may make bananas vulnerable to disease attack (Thompson and Burden, 1995). Several symptoms have been reported on banana fruits, many of which may occur during transportation and storage, because of unhealthy ripening and/or because symptomless fruits never receive any treatment before transportation and marketing (Lim et al., 2002). The genus Colletotrichum and its teleomorph Glomerella are considered to be major plant pathogens worldwide. They cause significant economic damage to crops in tropical, subtropical, and temperate regions (Bailey and Jeger, 1992). Anthracnose disease caused by Colletotrichum musae (Berk. and Curt.) is considered of the most important worldwide diseases of banana fruits, and it is particularly associated with losses due to scratches and wounds caused by handling and transport processes (Wardlaw, 1934). Since the disease can infect ripe banana fruits, more losses can also occur at market. Banana fruits can be infected by the fungus in the field at any time within growing season (Simmonds and Mitchell, 1940). Banana anthracnose often begins as an invisible disease on green fruits in the field. As the fruits ripen, the accumulation of phytoalexins restricts the successful penetration of the fungus (Jeger et al., 1995; Turner, 1995). The shipping of banana fruits as bunches and with subsequent ripening at high temperature, may magnify the anthracnose problem (Meredith, 1960). Fungus can invade green finger necks when damaged by flexing (Wardlaw, 1995). A combined application of molecular diagnostic tools along with traditional morphological characterization is an appropriate and reliable approach for studying Colletotrichum species complexes (Cannon et al., 2000). This study was conducted to identify the casual agent of anthracnose lesions on banana fruits collected from the markets and to examine morphological characteristics, pathogenicity and genetic diversity of the fungal isolates.

\section{MATERIAL AND METHODS}

\section{Fungal isolation}

Banana fruits with typical symptoms of anthracnose disease collected from different markets in various locations in Riyadh were subjected to pathogen isolation. Banana fruits were surface disinfected by washing them with $1 \%$ sodium hypochlorite for $1 \mathrm{~min}$, and then washed 
extensively with sterile distilled water. Diseased parts were cut into small pieces and transferred to the surface of potato dextrose agar (PDA) plates using sterile forceps. Plates were incubated at 25 $\pm 1^{\circ} \mathrm{C}$, and the isolates obtained were purified by transferring monosporic isolates to fresh PDA.

Cultural characteristics of the isolates obtained were examined after incubation for 7 days on PDA, malt yeast agar (MYA), and Sabouraud dextrose agar (SDA). Conidial morphology and measurements were determined microscopically after incubation on PDA at $25 \pm 1^{\circ} \mathrm{C}$ for 10 days.

\section{Pathogenicity assay}

For the pathogenicity test, healthy green banana fruits were surface-sterilized with $70 \%$ ethanol, and five wounds were made in each fruit using sterilized wooden rod. In each fruit, four wounds were inoculated with mycelial plugs $(3 \mathrm{~mm})$ from a 7-day-old culture of each isolate, and one was treated with uncultured pure PDA as a control. Three replicates were made for each treatment. Inoculated banana fruits were covered with plastic, and incubated at $25 \pm 1{ }^{\circ} \mathrm{C}$ for 5 days.

\section{DNA extraction and microsatellite-primed polymerase chain reaction (MP-PCR)}

Eleven isolates were cultured in potato dextrose broth (PDB) at $25 \pm 1^{\circ} \mathrm{C}$ in a $250-\mathrm{mL}$ conical flask for 7 days without shaking. Mycelia were harvested and ground to a fine powder in liquid nitrogen. DNA was extracted using $50 \mathrm{mg}$ ground mycelia as described by AbdElsalam et al. (2007). Three microsatellite markers were used [(CAG)3, (GTG)3, (T3B)] to study the genetic variations within the fungal isolates. PCR was performed in a volume of 25 $\mu \mathrm{L}$ containing $10 \mathrm{ng}$ purified DNA, $20 \mathrm{pM}$ primer, $10 \mathrm{mM}$ of each dNTP, $1 \mathrm{U}$ Taq polymerase (ABgene, Epsom, UK), 10X PCR buffer and $10 \mathrm{mM} \mathrm{MgCl}$. Amplifications were carried out under the following conditions: $3 \mathrm{~min}$ at $95^{\circ} \mathrm{C}$ for denaturation, 40 cycles of $1 \mathrm{~min}$ at $94^{\circ} \mathrm{C}, 1$ min at $50^{\circ} \mathrm{C}$ and $1 \mathrm{~min}$ at $72^{\circ} \mathrm{C}$, with a final extension of $10 \mathrm{~min}$ at $72^{\circ} \mathrm{C}$. PCR products were separated by gel electrophoresis with a $1.5 \%$ agarose gel in $1 \mathrm{X}$ TAE buffer at $4.5 \mathrm{~V} / \mathrm{cm}$ for 2 h. A DNA marker (a 100-bp DNA ladder; Roche, Germany) was loaded together with PCR products to determine fragment size. DNA was visualized by UV fluorescence after staining with ethidium bromide. UVIsoft analysis (Gel Documentation and Analysis Systems, Uvitec, Cambridge, UK) was used to capture the images and to calculate molecular size.

\section{RESULTS}

\section{Fungal identification}

Eleven single-spore C. musa isolates were obtained from banana fruit samples with anthracnose lesions collected from different markets in Riyadh. PDA was the best medium for fungal growth, in which the isolates grew fast, forming a white aerial mycelium, turning an orange color with age, and produced loose colonies (Figure 1). Several pinkish structures developed abundantly on the incubated culture surface after 10 days, which were mostly acervuli including dark-orange to pinkish conidia (Figure 1). Conidial structures mostly coalesced together. Conidia were aseptate, hyaline and mostly ellipsoid, ranging from 12-17 x 4-8 mm (average of $13.5 \times 6.0 \mathrm{~mm}$ ) in size (Figure 2C). 

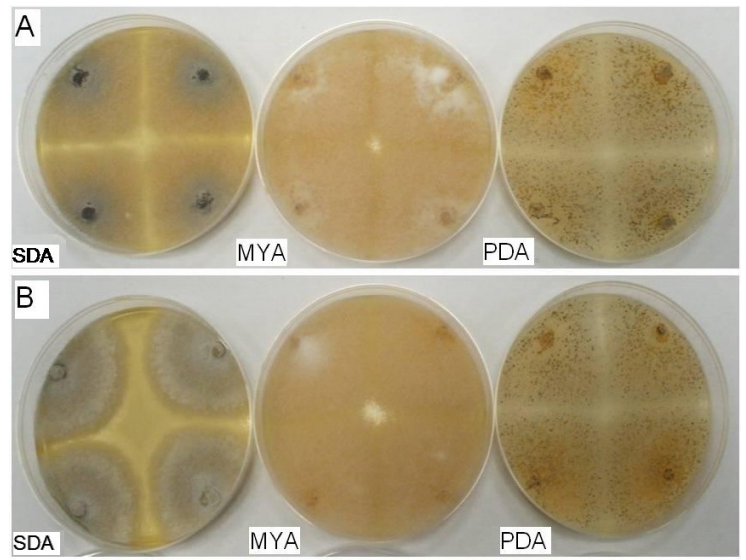

Figure 1. Cultural characterization of Colletotrichum musae on Sabouraud dextrose agar (SDA), malt yeast agar (MYA), and potato dextrose agar (PDA). A. Isolate No. 1. B. Isolate No. 5.

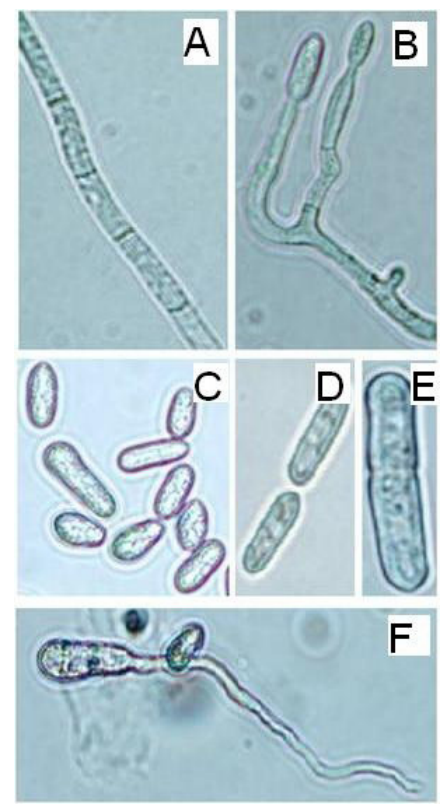

Figure 2. Microscopic characteristics of Colletotrichum musae isolates. A. Septate mycelia. B. Conidiophores. C.-E. Conidia. F. Germinating spore.

\section{Pathogenicity}

Inoculated banana fruits showed typical anthracnose symptoms after incubation at $25^{\circ} \mathrm{C}$ for 5 days, which were sunken, circular, necrotic, and dark-brown lesions (Figure 3B). Later, whitish mycelia developed on the lesions with subsequent orange-colored conidial structures. 


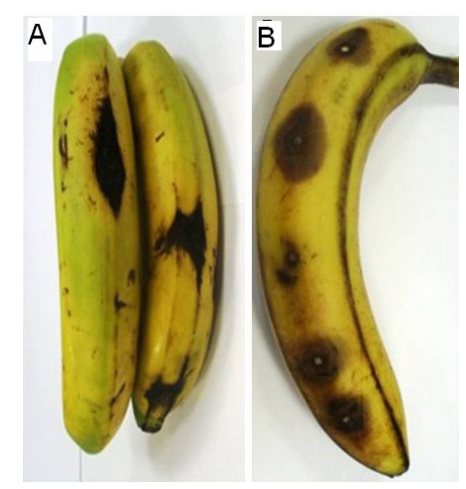

Figure 3. Pathogenic behavior of Colletotrichum musae on banana fruits. A. Naturally anthracnosed fruits. B. Artificially anthracnosed fruit.

\section{Intraspecific variability of $C$. musae isolates}

Microsatellite analysis of nuclear DNA was performed on 11 isolates of C. musae. Figure 4 shows a dendrogram of 11 isolates based on cluster analysis of banding patterns using 3 combined primers [(CAG)3, (GTG)3, (T3B)]. MP-PCR data were collected in a digital format to be used as a basis for a phylogenetic analysis of 11 C. musae isolates. UPGMA analysis made it possible to discriminate all the isolates of this study. The dendrogram shows a clear distinction between two main clusters. The results of MP-PCR analysis showed low genetic diversity among the $C$. musae isolates with three discrete groups identified with about $83 \%$ similarity. Isolates 6 and 7 showed high genetic relatedness (100\%). The genetic similarities among all $C$. musae taxa displayed 83 to $100 \%$ similarity in intraspecific comparisons.

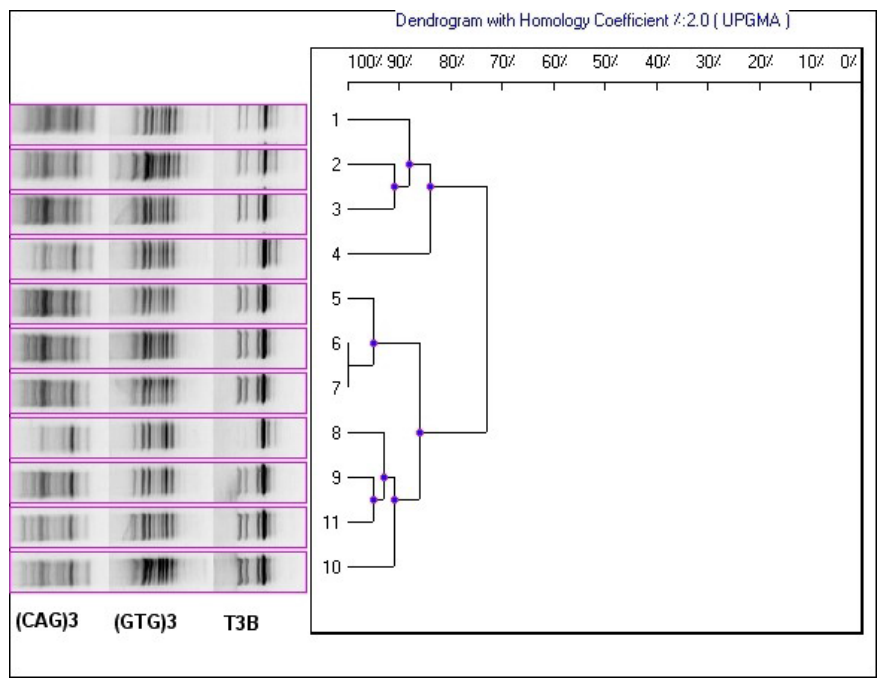

Figure 4. Dendrogram of 11 Colletotrichum musae isolates based on cluster analysis of MP-PCR data using 3 combined primers [(CAG)3, (GTG)3, (T3B)]. 


\section{DISCUSSION}

Eleven anthracnose isolates were obtained from diseased banana fruits imported into Saudi Arabia. According to colony characters and microscopic data of conidial measurements of these isolates and after comparing data from previous studies, they could be identified as C. musae. Our data are in harmony with those reported by Sutton and Waterson (1970). The isolates tested were identified as C. musae by comparing their morphological characteristics with those reported by Sutton and Waterson (1970). Conidial diameters and morphological characteristics of the isolates were the same as those described for C. musae. Moreover, appressorium characteristics of the isolates were almost like those of C. musae characteristics, including colony shape on PDA, and conidial color confirmed that the isolates are of C. musae. Our findings in the current study are in agreement with the results of Lim et al. (2002). The pathogenic isolates showed cultural characteristics on bananas, i.e., colony color and growth texture, that were morphologically similar to that previously described for the banana pathogen C. musae (Sutton, 1980; Price, 1995; Photita et al., 2005). Based on the pathogenicity observed after inoculation of healthy banana fruits with mycelial plugs through wounds on the banana fruits, and comparing the results obtained with the typical symptoms of anthracnose disease by C. musae, it is clear that our isolates are able to cause anthracnose disease. All $C$. musae isolates were pathogenic on bananas. Infections stimulate ripening of fruits, and lesions elongate with ripening. On ripening fruits, sunken brown spots develop with orange acervuli (Sutton and Waterston, 1970; Stover, 1987). C. musae and C. gloeosporioides have been found as endophytes in banana, but these fungi also cause anthracnose of banana fruits (Photita et al., 2001), supporting the idea that pathogens may spend part of their lives in an endophytic stage (Brown et al., 1998). Despite its importance as a plant pathogen and in post-harvest diseases, there have been relatively few genetic studies on the genus Colletotrichum in the past five years (Lubbe et al., 2004; Photita et al., 2005; Farr et al., 2006; Than et al., 2008). MP-PCR methods have been employed successfully to differentiate populations of C. musae. Based on genetic similarities, UPGMA cluster analysis was conducted to graphically display grouping between isolates. UPGMA cluster analysis clustered the isolates into two main groups according to their previous observed cultural characteristics. The genetic similarities among all C. musae isolates oscillated between 83 and 100\% in intraspecific comparisons. The patterns showed extensive homology, which may therefore restrict the use of this technique for typing individual isolates. C. musae has generally been recognized as a species distinct from $C$. gloeosporioides (Holliday, 1980; Sutton, 1980; Jones, 2000). According to data derived from microsatellite analysis of our isolates, very low genetic variation was observed between isolates of C. musae. In previous studies with populations of C. acutatum and C. fragariae from strawberries and $C$. musae from bananas, little genomic variation within each species was observed using different molecular methods (Freeman et al., 1993; Freeman and Rodriguez, 1995; Nazriya et al., 2007). In contrast, a high level of diversity was observed in populations of C. gloeosporioides from apples, avocados, and strawberries and of C. musae from bananas (Gunnell and Gubler, 1992; Prusky and Plumbley, 1992; Freeman et al., 1993; Freeman and Rodriguez, 1995). Understanding the genetic structure of pathogen populations may lead to improved strategies for managing the disease. The results suggest that C. musae, which has not been reported in Saudi Arabia, could be introduced into the country through imported bananas and may cause diseases in other plant species. 


\section{ACKNOWLEDGMENTS}

The authors gratefully acknowledge partial financial support by Distinguished Scientist Fellowship Program (DSFP), King Saud University. Also, this study was supported in part by grants from the National Plan of Science and Technology, King Abdulaziz City of Science and Technology, Riyadh, Saudi Arabia (10-BIO 965-10).

\section{REFERENCES}

Abd-Elsalam KA, Asran-Amal A and El-Samawaty AMA (2007). Isolation of high-quality DNA from cotton and its fungal pathogens. J. Plant Dis. Prot. 114: 113-116.

Bailey JA and Jeger MJ (1992). Colletotrichum: Biology, Pathology and Control. CAB International, Wallingford.

Brown KB, Hyde KD and Guest DI (1998). Preliminary studies on endophytic fungal communities of Musa acuminata species complex in Hong Kong and Australia. Fungal Divers. 1: 27-51.

Cannon PF, Bridge PD and Monte E (2000). Linking the Past, Present, and Future of Colletotrichum Systematics. In: Colletotrichum: Host Specificity, Pathology, and Host-Pathogen Interaction (Prusky D, Freeman S and Dickman MB, eds.). APS Press, St. Paul, 1-20.

Farr DF, Aime MC, Rossman AY and Palm ME (2006). Species of Colletotrichum on Agavaceae. Mycol. Res. 110: 13951408.

Freeman S and Rodriguez RJ (1995). Differentiation of Colletotrichum species responsible for anthracnose of strawberry by arbitrarily primed PCR. Mycol. Res. 99: 501-504.

Freeman S, Pham M and Rodriguez RJ (1993). Molecular genotyping of Colletotrichum species based on arbitrarily primed PCR, A + T-rich DNA, and nuclear DNA analyses. Exp. Mycol. 17: 309-322.

Gunnell PS and Gubler WD (1992). Taxonomy and morphology of Colletotrichum species pathogenic to strawberry. Mycologia 84: 157-165.

Holliday P (1980). Fungus Disease of Tropical Crops. Cambridge University Press, Cambridge.

Jeger MJ, Eden-Green S, Thresh JM, Johanson A, et al. (1995). Banana Diseases. In: Bananas and Plantains (Gowen S, ed.). Chapman \& Hall, London, 317-381.

Jones DR (2000). Disease of Banana, ABACÁ and Enset. Commonwealth Mycological Institute, Kew.

Lim J, Lim TH and Cha B (2002). Isolation and identification of Colletotrichum musae from imported bananas. Plant Pathol. J. 18: 161-164.

Lubbe CM, Denman S, Cannon PF, Groenewald JZ, et al. (2004). Characterization of Colletotrichum species associated with diseases of Proteaceae. Mycologia 96: 1268-1279.

Meredith DS (1960). Studies on Gloeosporium musarum Cke. \& Mass. causing storage rots of Jamaican bananas. I. Anthracnose and its chemical control. Ann. Appl. Biol. 48: 279-290.

Nazriya NF, De Costa DM and Azhaar AS (2007). Genomic Variations of Colletotrichum musae Morphotypes Infecting Banana Varieties of Sri Lanka. Vol. 12, Part I. Proceedings of the Peradeniya University Research Sessions, Sri Lanka, November 30.

Photita W, Lumyong P and Hyde KD (2001). Endophytic fungi of wild banana (Musa acuminata) at Doi Suthep Pui National Park, Thailand. Mycol. Res. 105: 1508-1513.

Photita W, Taylor PWJ, Ford R, Hyde KD, et al. (2005). Morphological and molecular characterization of Colletotrichum species from herbaceous plants in Thailand. Fungal Divers. 18: 117-133.

Price NS (1995). The Origin and Development of Banana and Plantain Cultivation. In: Bananas and Plantains (Gowen S, ed.). Chapman and Hall, London, 317-381.

Prusky D and Plumbley RA (1992). Quiescent Infections of Colletotrichum in Tropical and Subtropical Fruits. In: Colletotrichum: Biology, Pathology and Control (Bailey JA and Jeger MJ, eds.). CAB International, Wallingford, 289-307.

Simmonds JH and Mitchell RS (1940). Black end and anthracnose of the banana with special reference to Gloeosporium musarum Cke. \& Mass. Bull. Country Sci. Industr. Res. Aust. 131: 61-63.

Stover RH (1987). Diseases and Disorders. In: Bananas (Stover RH and Simonds NW, eds.). Longman, New York, 281-323.

Sutton BC (1980). The Coelomycetes. Commonwealth Mycological Institute, Kew.

Sutton BC (1992). The Genus Glomerella and its Anamorph Colletotrichum. In: Colletotrichum Biology, Pathology and Control (Bailey JA and Jeger MJ, eds.). CAB International, Wallingford, 1-26.

Sutton BC and Waterston JM (1970). Colletotrichum musae. CMI Description of Pathogenic Fungi and Bacteria, No. 222. 
Eastern Press, London

Than PP, Jeewon R, Hyde KD, Pongsupasamit S, et al. (2008). Characterization and pathogenicity of Colletotrichum species associated with anthracnose on chilli (Capsicum spp.) in Thailand. Plant Pathol. 57: 562-572.

Thompson AK and Burden OJ (1995). Harvesting and Fruit Care. In: Bananas and Plantains (Gowen S, ed.). Chapman \& Hall, London, 403-433.

Turner DW (1995). The Response of the Plant to the Environment. In: Bananas and Plantains (Gowen S, ed.). Chapman \& Hall, London, 206-229.

Wardlaw CW (1934). The nature and occurrence of pitting diseases and fruit spots. Trop. Agric. 11: 8-13.

Wardlaw CW (1972). Banana Diseases. 2nd edn. Longman, London. 